COMPUTERS IN QUANTITY SURVEYING 


\section{COMPUTERS IN QUANTITY SURVEYING}

R. J. ALVEY F.R.I.C.S., F.I.Q.S.

Principal Lecturer in Quantity Surveying,

Trent Polytechnic 
(C) R. J. Alvey 1976

All rights reserved. No part of this publication may be reproduced or transmitted, in any form or by any means, without permission.

First published 1976 by THE MACMILLAN PRESS LTD

London and Basingstoke Associated companies in New York Dublin Melbourne Johannesburg and Madras

ISBN 978-0-333-17973-4 ISBN 978-1-349-15681-8 (eBook)

DOI 10.1007/978-1-349-15681-8

Set in IBM Press Roman by PREFACE LTD Salisbury, Wilts

This book is sold subject to the standard conditions of the Net Book Agreement.

The paperback edition of this book is sold subject to the condition that it shall not, by way of trade or otherwise, be lent, re-sold, hired out, or otherwise circulated without the publisher's prior consent in any form of binding or cover other than that in which it is published and without a similar condition including this condition being imposed on the subsequent purchaser. 
This book is dedicated to my wife Beryl, for her patience during its preparation 


\section{CONTENTS}

Preface $\quad$ xi

1. The Impact of the Computer 1

The Computer's Abilities 1

Benefits of using a Computer 2

Impact of the Computer $\quad 3$

The Use of the Computer in the Construction Industry 4

$\begin{array}{ll}\text { References } & 6\end{array}$

2. The Nature of the Computer 8

$\begin{array}{ll}\text { Analog Computers } & 8\end{array}$

Digital Computers $\quad 9$

Hybrid Computers $\quad 11$

Electronic Computers $\quad 11$

$\begin{array}{ll}\text { Minicomputers } & 12\end{array}$

$\begin{array}{ll}\text { References } & 13\end{array}$

3. Components of an Electronic Digital Computer 14

$\begin{array}{ll}\text { The Central Processor } & 15\end{array}$

$\begin{array}{ll}\text { Backing Store } & 19\end{array}$

$\begin{array}{ll}\text { Computer Configuration } & 24\end{array}$

Computer Processing Techniques $\quad 24$

Input Devices for New Data Entry $\quad 27$

Output Devices for Results $\quad 29$

References $\quad 30$

4. Operating the Computer 32

$\begin{array}{ll}\text { Analysis } & 32\end{array}$

$\begin{array}{ll}\text { Flowcharts } & 34\end{array}$

$\begin{array}{ll}\text { References } & 39\end{array}$

5. Computer Programs 40

Operating-system Programs $\quad 40$

User-written Programs $\quad 41$

Compiling and Testing Programs $\quad 44$

$\begin{array}{ll}\text { Subroutines } & 46\end{array}$

$\begin{array}{ll}\text { Macro Instructions } & 47\end{array}$

$\begin{array}{ll}\text { References } & 47\end{array}$ 
6. Information Resources 49

The Building Process 49

Communications and Flow of Information $\quad 53$

Data Coordination $\quad 56$

Coding $\quad 58$

$\begin{array}{ll}\text { Coordinated Information System } & 61\end{array}$

References $\quad 64$

7. Standardisation of Information 65

$\begin{array}{ll}\text { Methods of Measurement } & 65\end{array}$

Standard Descriptions $\quad 66$

Libraries of Descriptions $\quad 72$

Classification Categories $\quad 74$

Bills of Quantities Formats $\quad 75$

Programs for Quantity Surveyors $\quad 78$

$\begin{array}{ll}\text { References } & 79\end{array}$

8. Bills of Quantities by Computer 80

$\begin{array}{ll}\text { Procedures } & 80\end{array}$

Computer Processing $\quad 89$

Rogue Items $\quad 94$

$\begin{array}{lr}\text { Short Coding } & 96\end{array}$

$\begin{array}{ll}\text { References } & 97\end{array}$

9. Unit Quantities 99

$\begin{array}{lr}\text { Procedure } & 99\end{array}$

$\begin{array}{ll}\text { Coding Unit Quantities Dimensions } & 108\end{array}$

Bills of Quantities from Unit Quantities $\quad 110$

$\begin{array}{ll}\text { References } & 114\end{array}$

10. The Use of the Computer for Ancillary Services 115

Bills of Quantities $\quad 115$

Bill Sortation $\quad 115$

$\begin{array}{ll}\text { Bill Pricing } & 116\end{array}$

Cost Planning and Cost Analysis $\quad 116$

$\begin{array}{ll}\text { Network and Constructional Analyses } & 120\end{array}$

Financial Forecasts, Interim Certificates and Final Accounts 131

$\begin{array}{ll}\text { Coordinated Information Systems } & 132\end{array}$

$\begin{array}{ll}\text { References } & 132\end{array}$

11. Computer Services 134

$\begin{array}{ll}\text { Consultancy Services } & 134\end{array}$

Application Packages $\quad 136$

$\begin{array}{lr}\text { Processing Services } & 143\end{array}$ 
Remote Computing $\quad 145$

Computer Personnel 147

References

12. Economics of Computerisation 151

$\begin{array}{ll}\text { Motivation } & 151\end{array}$

Computer Selection $\quad 152$

Effects of Computerisation $\quad 157$

References $\quad 159$

Appendix A Unit Quantity Library 160

Appendix B Inland Datel Services 164

Appendix C Glossary of Terms 166

Index 171 


\section{PREFACE}

Quantity surveyors are becoming increasingly involved in modern methods of data processing and are looking to the computer as a means of solving problems and providing techniques for the more effective use of their skills. The computer provides new techniques that the construction design team can utilise to the betterment of the design and construction processes. The changing economic climate and the introduction of new building techniques have demanded a closer liaison between the professions and the construction team with the object of providing coordinated information systems. Computerisation may be held to be an answer. A study of computers, therefore, is necessary if the quantity surveyor is to keep abreast of modern techniques.

Computer jargon can be very confusing and only confounds the layman; this tends to create an air of mystery. Nevertheless the introduction of computers has created a new professional with an expertise that the quantity surveyor cannot hope to replace. However, to utilise these new skills the quantity surveyor must have some knowledge of the techniques involved. This means that he should have a basic appreciation of the technicalities of computerisation and a knowledge of its potential applications.

This book is directed primarily at students who are preparing for the professional examinations of the Royal Institution of Chartered Surveyors, the Institute of Quantity Surveyors and the Institute of Building. It is hoped that it may also be found useful by students studying for degrees and diplomas in quantity surveying and building and for allied professions and practitioners.

The book makes a study of computers to provide a basic appreciation of their nature and characteristics and to give a better understanding of the manner in which computers may be used satisfactorily by the construction design team with particular reference to the quantity surveyor's needs.

I wish to acknowledge with gratitude all the help and cooperation given by many organisations and persons associated with the computer industry especially R. Aldridge, D. R. Judd and S. K. A. Raza and many others too numerous to mention. My special thanks are due to my colleagues at Trent Polytechnic for their encouragement, especially to Dr I. H. Seeley for his most helpful comments. Grateful thanks are also due to those quantity surveyors with whom I have had some stimulating discussions. Last and by no means least I wish to thank my family for their tolerance and understanding while this book was being prepared. 